\title{
A kortárs jazz esztétikai és etnikai konstrukciói: „cigány jazz” és zenei habitus
}

\author{
Havas Ádám \\ https://doi.org/10.51624/SzocSzemle.2018.2.6 \\ Beérkezés: 2018.02.08. \\ Átdolgozott változat beérkezése: 2018. 05. 10. \\ Elfogadás: 2018. 06. 08.
}

\begin{abstract}
Összefoglaló: Több mint 40 óra mélyinterjús kutatás és résztvevő megfigyelés elemzésére támaszkodó tanulmányom a roma származással kapcsolatos zenei diszpozíciók (habitusok) kortárs jazz-zenei mező viszonyrendszerében betöltött szerepét vizsgálja. Az etnikumhoz köthető jelentéssel bíró megkülönböztető sajátosságok diszpozicionális elemeit (értékelési, észlelési és kognitív sémáit) a bourdieu-i habitusfogalom nyomán alkotott zenei habitus (Rimmer 2012) koncepcióval vizsgálom, különös tekintettel a zenei szocializáció, csoportdinamika és az esztétikai distinkciók szempontjaira. Noha a foglalkozással definiált társadalmi csoport, a „zenész cigányság” fontos szerepet tölt be a populáris zene fejlődésében Magyarországon, a szociológia módszereivel idáig nem elemezték e dominált etnikum domináns (urbánus, többnyire „magyarcigány” jazz-zenész) frakciójának kulturális legitimitások hierarchiájában betöltött pozícióját a kortárs jazz szemszögéből.
\end{abstract}

Kulcsszavak: zenei habitus, Bourdieu, kulturális mező, jazz, cigányság

\section{Bevezetés}

„Nem kell Amerikába kimenni jazzt tanulni, (...) menjetek el a 8kerbe, és megtanultok a Kálcsitól zongorázni, ennyi."

A youtube-comment idézetként való beemelése talán szokatlan felütésnek hat egy tudományos munka elején, mégis, a szóban forgó kompozíció alatti hozzászólásban több olyan szempont lelhető fel, melyeket e tanulmány során bontok ki, és amik szorosan kapcsolódnak a magyar "jazzdiaszpórával” (Johnson 2002) kapcsolatos kutatási kérdéseimhez. A több szempontból is kényes témafelvetés elején - kezdve az egyes zenészek témával kapcsolatos érzékenységétől a múfaji besorolás problematikáján át a számos zenésszel személyes viszonyt ápoló, objektivitásra törekvő kutató sajátos pozíciójáig - fontos tisztázni, hogy a címben szereplő idézőjel tudatos gesztus, mely a konstruktivista elemzői szemléletnek kíván nyomatékot adni. Koránt sincs ugyanis

1 Az idézet a Liszt Ferenc-díjas Oláh Kálmán „Kálcsi” (jazz)-zongoramúvész Always című, neves nemzetközi díjat is elnyerő kompozíciója alatti youtube-comment stilizált verziója. Az eredetit lásd: https://www.youtube.com/watch?v=H9ytdSvMEnU. 
konszenzus arról, hogy létezik-e „cigány jazz” a '30-as évek Franciaországában kialakuló és Django Reinhardt nevéhez köthető „manouche jazz”, „gypsy jazz” vagy „szinti szving" néven is ismert, a zenetudomány és kultúrtörténet által kanonizált irányzaton kívül (lásd pl. Dregni 2004).

$\mathrm{Az}$ alábbi tanulmány szúkebben vett témája - vagyis a jellemzően többgenerációs zenészcsaládban, városi környezetben nevelkedett, a magyarországi cigányság döntő többségét adó „magyarcigány” vagy romungró ${ }^{2}$ származású jazzmuzsikusok zenei/ esztétikai diszpozícióinak vizsgálata - egy 2014-ben indult kutatás részét képezi (Havas-Ser 2017). Az erőteljesen fővárosban koncentrált kortárs magyar jazzszcéna ${ }^{3}$ szimbolikus és gazdasági dimenziók mentén korábban részletesen vizsgált rétegződésében (Havas 2017) a roma etnikum történeti és strukturális okoknál fogva sajátosan jelenik meg (Retkes 2014; Zipernovszky 2017). Cikkem középpontjába a dominált etnikum domináns frakciójának zenei gyakorlatait helyezem, azzal a céllal, hogy a zenei szocializáció kondicionálta múvészi praxisok és a jazz-zenei erőtéren belüli presztízshierarchia közti kapcsolatokat érzékeltessem, reflektálva eme összefüggések társadalmi alapjaira is. Röviden, dolgozatom e zenei mikrokozmosz elitcsoportjának zenei gyakorlatait szélesebb kulturális distinkciók összefüggésrendszerében értelmezi. ${ }^{4}$

$\mathrm{Az}$ interjúelemzés és etnográfiai leírás megfelelő kontextualizálása céljából ezért először röviden összegzem a témafelvetésem szempontjából releváns eddigi kutatási eredményeimet, majd a kulturális legitimáció és a jazz viszonyával kapcsolatos fó téziseim kerülnek bemutatásra. Az elméleti fejezetet követô empirikus részekben végül a zenei habitus (zenei) szocializációval, életstílussal és esztétikai distinkciókkal összefüggő aspektusait elemzem.

Rimmer (2012) kutatását leszámítva tanulmányom az első, amely a jazz müfaján belüli jelentéssel bíró különbségtételek szélesebb társadalmi összefüggéseit Bourdieu habitusfogalma segítségével kísérli meg elemezni. A tanulmány elkészültéig más, a fogalmat előtérbe helyező tanulmányról nem szereztem tudomást. ${ }^{5} \mathrm{Az} 5$ „follow up” interjút nem számítva e tanulmányban a 27 félig strukturált mélyinterjú ( 45 óra) közül főleg (de nem kizárólag) arra a hétre fókuszálok, amikor azokat a különböző generációba tartozó és eltérő hangszereken játszó roma zenészekkel készítettem. Kutatásom „kvázietnográfiai” jellegú, mert az interjúelemzések mellett „terepen” (pl. jazzklubokban) végzett résztvevő megfigyeléseimből is sokat merítek, ezenkívül az elemzés során videóanyagokra, interjúkra, közösségi médiára, újságcikkekre, lemezekre, számokra és még egy lemezborítókép szimbolikájára is támaszkodom.

2 Arányuk a teljes cigány népesség 80\%-a (Kovai 2015: 9).

3 A bourdieu-i mezőfogalom mellett a „szcéna” és „erőtér” fogalmakat is alkalmazom, mely a dolgozat fő elméleti referenciája. Részletesebben a „szcéna”, „szubkultúra” és „mező” koncepciókkal kapcsolatos elméleti dilemmákról a kutatás kontextusában lásd Havas-Ser (2017), Havas (2018a), valamint az egyes koncepciókról bővebben Bennett (2004) és Kacsuk (2005) munkáit.

4 Szociológiai nézőpontból a „cigánykutatásokkal” kapcsolatos strukturális és kulturális diskurzusokról lásd pl. Ladányi-Szelényi (2005) és Stewart (1994), a kulturális antropológia és zenetudomány szemszögéből pedig Kovai (2015), Kovalcsik (2006) és Könczei (2011) munkáit. A zene szerepéről és a különböző stílusok jelentéstartalmairól a cigányság körében részletesen lásd Kovai (2015: 59-73), valamint Stewart (1994) írásait.

5 Prior (2013: 183) tanulmányában ugyan említi a fogalmat, de „csak" mint termékeny elméleti referenciát, maga nem végzett a fogalmat középpontba állító empirikus kutatást. 


\section{A jazz-zenei mező felemelkedése és a muzsikus cigányok ${ }^{6}$}

\section{A roma származású jazz-zenészek reprezentációja a mainstream/free megkülönböztetés kontextusában}

A kultúraszociológia és a jazz studies módszertani és elméleti referenciáira támaszkodó kutatás bevezető tanulmányában Ser Ádámmal (Havas-Ser 2017) összegeztük a jazzel kapcsolatos társadalomtudományi munkák témafelvetéseit, hogy rávilágítsunk, milyen különböző rasszal (Lopes 2002), kreatív munkavállalással (Becker 1951; Umney-Kretsos 2015), kulturális hierarchiával (Lopes 2000) és dzsenderrel ${ }^{7}$ (Johnson 2000) összefüggő kontextusokban tölt be központi szerepet a jazz kutatása. A jellegzetesen modern társadalmi-kulturális gyakorlatként (Johnson 2002: 96-113) - tehát korántsem kizárólag zenei praxisként - értelmezett múfaj a huszadik századi társadalmi változások és kulturális hierarchiák történeti dinamizmusa folytán Magyarországon is sajátos emancipációs utat járt be (lásd pl. Havadi 2011).

A kortárs jazzszcéna rétegződésével kapcsolatos kutatási kérdéseink közül a müfajon belüli szimbolikus különbségtételek és presztízs kapcsán merült fel legmarkánsabban a „cigányság” mint megkülönböztetett és megkülönböztető csoport, melyet interjúalanyaim (mainstream és free jazzt játszó zenészek egyaránt) elsősorban a mainstream jazzt játszókkal, ill. annak krémjével azonosítanak. A terepnaplókban dokumentált résztvevő megfigyelések és a mélyinterjúk elemzése alapján a pozícióés presztízsszerzésben a free és mainstream jazz mint rendszert alkotó alapoppozíció kulcsfontosságú szerepet tölt be (Havas 2017). Az interjúkból rekonstruált ellentétpárok szempontjaihoz való viszony strukturálja a szcénát, és egyúttal történetileg kondicionált társadalmi viszonyokat is megtestesít: ${ }^{8}$

(...) mainstream és free zenészek nézőpontjait visszaadó interjúrészletek és kritikák lényege megragadható a tradicionalista-progressziv, múltközpontú-jelen idejü, ideologikus-esztétikai és ortodox-újító ellentétpárok révén (Havas 2017: 179).

Elemzésem egyik fő következtetése szerint, a '40-es évek közepén Amerikában kialakult mainstream jazz esztétikájának „szentháromságát” (a sztenderdek ismeretét, a jazzes frazírt és a szvinges lüktetést) a roma jazzisták intenzíven képviselik, ami megjelenik a jazz fenti definíciójához való dogmatikus ragaszkodásban, a tradícióértelmezés el- és kisajátításában, valamint a kizárási és kooperatív játszmákban, melyekben a rokonsági viszonyok központi szerepet töltenek be. Mint látni fogjuk, e free és mainstream zenészek által viszonylag homogénnek látott, belülről azonban meghatározó habituális szempontok alapján differenciált csoport a nem roma szár-

6 A fejezetcím Lopes (2002) könyvcímének (The Rise of a Jazz Art World) parafrázisa.

7 A magyar tudományos életben a dzsender bevett, kanonikus szóhasználatnak számít, a társadalmi nemeknek fordított gender szinonimájaként használják (lásd pl. Hadas 2011). A dzsender alkalmazásának praktikus előnye, hogy egyetlen szó (és idomul a magyar kiejtéshez, ahogy a "dzsentri” is idővel bevett szóhasználattá vált).

8 E tanulmányban terjedelmi okok miatt nem térek ki részletesen a kortárs magyar jazzszcéna presztízshierarchiáját meghatározó mainstream/free különbségtételre, melyet korábban (lásd pl. Havas 2017, 2018a, 2018b) részletesen elemeztem. A free és mainstream jazz oppozíció 14 szempont szerinti összegzését lásd Havas (2017: 174). 
mazású mainstream zenészek nézőpontjából is elitcsoportként reprezentálódik. A mainstream tradícióhoz való erőteljes ragaszkodás, a megkérdezettek által érzékelt „arisztokratikus” megnyilvánulások, továbbá a zenei szituációkban (pl. jam session során) tapasztalt konfliktusok folytán a szakmai tisztelethez egyúttal távolságtartás („distinkció”), a „másság” pejoratív asszociációi társulnak. A következő fejezetekben a kortárs jazzszcéna rétegződésében és presztízshierarchiájában alapvető fontosságú mainstream/free jazz distinkció egy sajátos aspektusát világítom meg, nevezetesen a mainstream jazz elitpozícióit betöltő roma származású jazz-zenészek múvészeti gyakorlatait kondicionáló zenei habitust. Ha tetszik, e tanulmányban a bináris oppozíciók kifeszítette erőtér mainstream pólusára fókuszálok.

\section{Zenész cigányok a legitimációs erôtérben, avagy hogyan kerülnek a kávéházból a (müvészetek) palotá(já)ba?}

Kulcsfontosságúnak tartom röviden felvázolni a cigány muzsikusok és a jazz viszonyának témafelvetéseim szempontjából meghatározó történeti aspektusát. A jazz térnyerése Magyarországon nem volt konfliktus nélküli. A többségi társadalom szórakoztatását monopolizáló cigányzenét vagy magyar nótát (Brown 2000: 124; Schneider 2006: 24-29) ${ }^{9}$ játszó városi cigányzenészek az első világháborút követően kollektíve lázadtak fel az Amerikából beszivárgó és a városi környezetben szintén népszerű, gazdasági konkurenciát jelentő jazzel szemben (Zipernovszky 2017). A gazdasági érdekkonfliktus mellett a jazz térnyerése a nemzeti kultúrára való fenyegetésként jelent meg, és a kulturális amerikanizáció veszélyét jelentette. A társadalom félperifériáján lévő „szignifikáns Másik” muzsikus cigányság a nemzeti kultúra védelmezőjeként lépett fel a racializált, „külső Másikkal” szemben (Federmayer 2017), amit az amerikai feketék jelentettek. Míg a felszentelt komolyzene a schönbergi atonális és Sztravinszkij-féle neoklasszikus irányvonalak között polarizálódott, addig az épp intézményesülő populáris zenei mezőt részben a fenti racializált-etnicizált státuszküzdelem határozta meg két szignifikáns „Másik” között (Brown 2000).

Az '50-es évektől kezdve azonban e réteg leszármazottai egyre nagyobb arányban képviselték magukat a mainstream jazzt játszók között (Retkes 2014). E generációs váltásban tetten érhető a kávéházi cigányzene jelképezte „szórakoztató”, „kiszolgáló” paradigmából való elmozdulás a magas kulturális gyakorlatokkal asszociált jazz felé (Peterson 1967), ${ }^{10}$ ahol a fő referenciák a jazz modernista fordulatához, tehát a '40-es évek utáni amerikai bebophoz kötődnek, szemben a „szvinges tánczenével” (Havas 2017). E generációs és „műfaji” váltás egyúttal növeli a „fiúk” generációjának társadalmi mezőben való legitimációját, ha úgy tetszik, „integrációját” vagy „beágyazott-

9 A vidéki léthez köthető autentikus magyar népzene és az elsősorban urbánus közegben kialakuló cigányzene vagy „magyar nóta" közti tudományos különbségtételt a néprajzkutató Vikár Bélához, Bartókhoz és Kodályhoz köti a zenetudományi szakirodalom (Zipernovszky 2017: 67).

10 A generációs váltás kulturális legitimitások hierarchiájában történő átpozicionálása a kulturális termelés mezőjében bekövetkező változásokkal, pl. a tradicionális kávéházi cigányzene iránti kereslet csökkenésével van összefüggésben, melyekre itt részletesen nem térek ki, erről lásd pl. Jávorszky (1999), Retkes (2014) és Szakcsi (2016a, 2016b). 
ságát” is. Annak az állításnak, mely szerint a már jazzt játszó cigányzenészek számára a kulturális legitimitások hierarchiájában történő felfelé pozicionálás státuszkérdésekkel áll összefüggésben, a cigányzenei habitussal kapcsolatos kutatásom szempontjából két fontos következménye van, melyeket az empirikus részekben kísérlek meg árnyalni, illetve alátámasztani.

A jazz képviselte múvészi zene felé történő elmozdulásnak fontos, identitást meghatározó szerepe van. Ennek következtében tovább nyílik az olló, növelve a cigányság csoportjai közti státuszkülönbségeket a „magyarcigány” jazz-zenészek javára, akik egyfajta elitcsoportot képviselnek a dominált csoporton belül. Mindezt reprezentálja a városi életvitelük és a kultúra felszentelt tereihez köthető, magas legitimitással bíró intézményekben való megjelenésük (pl. Zeneakadémia, MÜPA, MOM Kulturális Központ). Másrészt a jazz olyan terep számukra - szemben a hagyományos, többnyire a többségi társadalom közép- és felső rétegeiből rekrutálódó ügyvédi vagy orvosi pályákkal (Gáti 2010) - , ahol a zenei szocializáció során belsővé tett zenei kompetenciáknak köszönhetően a többségi társadalom tagjai fölé tudnak kerekedni. Az „asszimilációs rezsim” (Kovai 2017) felfogásával szemben, ahol mindig a nem cigány „magyar” a követendő példa és viszonyítási pont, a jazz éppen azért válik izgalmas kutatási területté, mert olyan közeget jelent, ahol a (mainstream) jazz-zenész magyarcigányok foglalják el az arisztokrácia pozícióját és alkotnak elitcsoportot. Az elméleti fejezetben bemutatott zeneihabitus-koncepció (Rimmer 2012) az egyes múfajokon belüli hierarchizált, társadalmi jelentéssel bíró különböző distinkciókat hangsúlyozza, így - magyar empirikus anyagon alkalmazva - a jazzen belüli etnicizált különbségétételek logikájának megragadásához is megfelelő fogalmi eszköznek bizonyul.

\section{A zenei habitus alkalmazása a vizsgált összefüggések magyarázatában}

Rimmer (2012) kvalitatív kutatásaiban a bourdieu-i habitusfogalom alapján konstruált zeneihabitus-koncepció alkalmazásának előnyeire hívja fel a figyelmet, kiváltképp a zenei ízlés státuszharcban betöltött szerepének értelmezése során. A zenei habitus alatt a tartós diszpozíciók (kognitív, cselekvési és értékelési sémák) rendszerének a zenében való megjelenését értjük. Rimmer definíciója szerint (2012: 306) „a zenei habitus egy magyarázóeszközt kínál az egyének zenével való viszonyáról”, ${ }^{11}$ melyet a szocializáció során felhalmozott és belsővé tett kulturális tőke befolyásol. A fogalom alkalmazásával a kutatónak lehetősége nyílik a zenei kifejezőeszközök megválasztásának logikáján túl a zenehallgatás módozatainak és a különböző (zenei) stílusokat osztályozó gyakorlatok társadalmi alapelveinek megragadására is. A fogalom alkalmazása az etnikum, a származás és az esztétikai praxisok közti kapcsolatok értelmezésével kecsegtet a kortárs jazz-zenei mező kontextusában, röviden, a koncepció a

11 A fordítás az eredetiből a sajátom: H. Á. 
társadalom egyéb viszonyrendszereiben is igazodási alapként tételezett habitus zenei vonatkozásait jelenti.

Rimmer tanulmánya explicit kritikáját adja a társadalmi pozíció (osztályhelyzet) és ízlés kapcsolatát vizsgáló kvantitatív kutatások kiterjedt irodalmának (ChanGolthorpe 2007; Peterson 1992), melyek sokszor „általánosító képet festenek” (Rimmer 2012: 313) ${ }^{12}$ ízlés, kultúrafogyasztás és társadalmi pozíció viszonyáról. ${ }^{13} \mathrm{~A}$ zenei habitus alkalmazása a műfajokon belül múködő klasszifikációs sémák pontosabb megértésével kecsegtet, ami alapvető fontossággal bírhat az egyes stílusok belső differenciáltságát esetenként nem kellő súllyal tárgyaló (lásd pl. Atkinson 2011), a kultúrafogyasztás és a réteghelyzet összefüggéseit nagy mintán vizsgáló elemzések számára is. A habitusfogalomnak a zene szférájában való alkalmazása önmagában nem tekinthető fogalmi újításnak, maga Bourdieu is számos habitustípust különböztet meg; nyelvi habitust (1991: 81), akadémiai habitust (1988), dzsenderhabitust (2001), sőt kutatói stratégiájának meghatározó része a Distinction-ban lefektetett reprodukciós logikába illeszthető mezőelmélet különböző társadalmi kontextusokban való működtetése. ${ }^{14}$ A közös nevező, amiért a különböző habitustípusok megkülönböztetése elméletileg lehetséges, a meződinamika alapelveinek azonosságából fakad: a mezők szerkezetét és kialakulását meghatározó relációk és pozíciószerzések logikája azonos szabályok alapján szerveződik (lásd Bourdieu, 1993, 1996; Maanen 2009). A nemzetközi irodalomban bevett „mezőelemzés” (field analysis) ${ }^{15}$ a különböző nemzeti kontextusokban ezekben az alapmúvekben lefektetett elveket veszi alapul akkor is, ha a bourdieu-i elméletből kiinduló szerzők a mezőelmélet differenciálására törekednek (Varriale 2015; Hesmondhalgh 2006; Prior 2007), vagy erősen kritizálják annak alkalmazhatóságát a késő modern kulturális viszonyok között (Hennion 2007; Lamont 1992).

Korábbi tanulmányaimban (Havas 2017; Havas-Ser 2017) a jazz-zenei mezőt olyan erőtérként értelmeztem, melyet a legitim jazzdefiníció ki- és elsajátítási harcai jellemeznek, mely harcok logikája pontosan megragadható a mainstream és free jazz különbségtételt meghatározó főbb oppozíciók által. Ilyen alapoppozíciónak tekintettem például a professzionális (a freejazz-zenészek által pejoratív felhanggal „technokratának" címkézett) mainstream jazz-zenész és az autonóm múvész zenei kompetencián túlmutató ethoszának ellentétét, melyet mélyinterjúk alapján rekonstruáltam. A mezőelmélet konfliktuselméleti megközelítéséből egyrészt a szimbolikus és gazdasági profitok kijelölte erőtérben folyó legitimációs harcok logikáját megragadó komplex fogalmi hálót veszem át, másrészt azt a már említett relacionális szemléletet, mely

12 Saját fordításom: H. A.

13 A stílusokat átfogó nagy gyűjtőkategóriák (jazz, rock, techno stb.) a múfajokon belüli distinkciókat sokszor elfedik. Rimmer joggal hívja fel a figyelmet az egy-egy stíluson belüli alvariációk jelentőségére, pl. csak a metálzenében megkülönböztethető legalább 10 alfajt szélesebb társadalmi distinkciók indikátorának is tekinthetjük.

14 Lásd Hadas Miklós tanulmányát (2015) Bourdieu Férfiuralom című könyvéről, mely „paradigmaexpanziónak” értelmezi a habitus társadalmi nemekre való kiterjesztését, pl. a libido dominandi bourdieu-i kulcskoncepció mint maszkulin habitus értelmezhető.

15 A nemzetközi kultúraszociológia nívós orgánuma, a Cultural Sociology 2013-ban külön számot is szentelt e kutatási gyakorlatnak, melyben eltérő módszertani apparátust felvonultató szerzők különböző nemzetek kulturális mezőinek elemzései mellett elméleti-összegző cikkeket is publikáltak (pl. Savage-Silva 2013). 
tudatosan reflektál arra, hogy a kutató által osztályozott csoportok - esetünkben a free és mainstream zenészek - egyben sajátos habitussal rendelkező osztályozó és típusalkotó csoportok is. Ebben az elméleti keretben a zenészek pozíciószerzéseinek alapelvei értelmezhetők az oppozíciós logika szerint szerveződő racionalizálási stratégiák alapján, ami alatt a különböző pozíciókat betöltő zenészek legitimációs esztétikai-ideológiai diskurzusait értem, amelyek tipizálására szintén kísérletet teszek.

A magyar jazz - azon belül is a mainstream és free jazz distinkció - továbbá azért izgalmas elemzési terep, mert e középszintű erőtér történeti és társadalmi kondicionáltságánál fogva sajátosan képez le szélesebb társadalmi viszonyrendszereket, valamint azok esztétikai elvekben és gyakorlatokban megjelenő jelentéseit. Egyetértésben azon szerzőkkel, akik e kulturális gyakorlat belső hierarchizálódását etnikummal, rasszal és más szélesebb kulturális jelenségekkel hozzák összefüggésbe (Lopes 2002), a '60-as években intézményesülö ${ }^{16}$ magyar jazz-zenei mező prizmája is megtöri a társadalom strukturális rendjét, és sajátos múködésmódja alapján leképezi azt. Az empirikus elemzés Magyarország „kvázifeketéinek”, az urbánus, cigány származású jazz-zenészek zenei diszpozícióinak vizsgálatát kínálja, és a zeneihabitus-koncepció alkalmazásával azt próbálja megragadni, hogy e muzsikusok miért részesítenek előnyben bizonyos múvészi kifejezőeszközöket másokkal szemben. Elsősorban roma származású zenészekkel készített interjúk rekonstrukciójára és etnográfiai leírásra támaszkodva - az elemzés során a (kora gyermekkori) zenei szocializáció Rimmer (2012) által (túl)hangsúlyozott szempontjai mellett - a rokonsági viszonyok szerepére, valamint a szocializáció révén kondicionált esztétikai preferenciák életvitelben is megragadható sajátosságaira is kitérek.

\section{Hangokba zárt folytonosság: a zenei szocializáció motívumai}

A később árnyalandó „cigány/nem cigány” különbségtétel egyik szempontja a zenei szocializációval kapcsolatos komparatív előnyök érzékelése. A belenevelődés/beletanulás distinkciót szinte az összes megkérdezett nem roma zenész említi, többségük szerint a jellemzően zenészcsaládba születő roma zenészeket „a hangszerrel kialakitott legtermészetesebb viszony jellemzi”, ami behozhatatlan előny egy olyan zenész számára, aki „nem nevelődik törzsi módon” (sic!) a zenébe. Az autodidakta zenész toposza is hangsúlyosabban van jelen a szocializációban, mint a nem roma zenészeknél. ${ }^{17}$ Ezzel összefüggésben jegyzem meg, hogy az interjúk során a Zeneakadémia ${ }^{18}$ két komoly előnyét említik. A (1) tudástőke átadásának terepét, ami a (szakonként eltérő színvonalú) oktatásban jelenik meg, és mint (2) szocializációs közeget, ahol a fiatal zenészek

16 Lásd Havadi írását a jazzklubhálózatról, valamint a kiváló forrásértékkel bíró Jazz Studium DIY kiadványt (1982-1990), mely maga is intézményesítette a free és mainstream jazz ellentétét, lévén, hogy elsősorban a free jazz referenciákat kanonizálta Magyarországon.

17 A magyar jazz egyik specifikuma, hogy számos elismert roma bőgős - nem túlzás azt állítani, hogy a „bőgősök krémje” (pl. Barcza Horváth József, Pecek Lakatos Krisztián, Orbán György) - autodidakta módon tanult jazzt játszani.

18 A továbbiakban a Liszt Ferenc Zenemúvészeti Egyetem Jazz Tanszékét a hallgatói szlengnek megfelelően „ZAK"-nak hívom. 
kapcsolatokat építenek, sokszor zenekart is alapítanak. Azon roma zenészek számára, akik rokonsági szálakon keresztül kapcsolatban vannak nagy presztízsű (roma és nem roma) zenészekkel (pl. azon prózai oknál fogva, hogy együtt nőnek fel), a ZAK mint társadalmi tőkét biztosító elitképző intézmény jóval kisebb fontossággal bír. A legitimitás sokkal inkább kötődik egy mainstream elit értékítéletéhez és „felszentelő” aktusaihoz - pl. azáltal, hogy kiket hívnak játszani -, mint a ZAK kölcsönözte legitimitáshoz, melyet a fenti lábjegyzetben említett bőgősök elismertsége is jól illusztrál.

A Montreux-győztes Balogh Roland gitáros szólóját hallgatva a virtuóz játék technikai nehézségéről kérdeztem egy a koncertet velem hallgató gitárost. A Baloghot személyesen nem ismerő jazzman a tisztelet hangján reagáló válaszában azt hangsúlyozta, hogy azt a magas szintű technikai tudást, melynek elemeit ő jelenleg csak gyakorolja, az épp játszó zenész valószínúleg már nagyon fiatalon, tizenévesen birtokolta. E szituáció jó példája annak, hogy a múvészi presztízsben mérhető életkor és a biológiai kor közti relációk (Bourdieu 1993) eltérő elvek mentén szerveződnek: a zenészcsaládba születettek körében a zenei tőkefelhalmozás jóval korábbra esik. Ahogy egy cigány származású bőgős lényegre törően megfogalmazza a szocializációval járó általa is érzékelt előnyt:

Édesapám olyan dolgokat tudott elmondani, amit mások a Liszten tanulnak meg. Más megtudja 25 évesen, én meg megtanultam 13 évesen, érted, most ez ilyen dolog. (...) A cigányok között van a legtöbb, aki zenész, nekünk ez a kultúránk. ${ }^{19}$

Míg mások a „konziban” vagy a Jazz Tanszéken tanulják a sztenderdeket, e zenei kompetenciák szempontjából „privilegizált csoport” tagjai sokszor nemzetközi versenyeken érnek el helyezést ${ }^{20}$ és/vagy már aktívan pénzt keresnek a zenéből: „mikor oda- [a ZAK-ra] kerültem, már nyakig benne voltam az éjszakában”. A korán megkezdett, zenészélettel együtt járó, a muzsikusok referenciacsoportja által elfogadott életstílus - az éjszakába nyúló muzsikálások, haknik, alkohol- és (esetleges) drogfogyasztás konfliktusokat szül még a zeneiskolákban is zenész növendékek és az iskolai elvárások közt, amit már középiskolás korukban megtapasztalnak a tanulók, ahogy a következő - jelenleg még nem érettségizett - 19 éves cigány származású interjúalanyom közléséből is kiderül:

„Más világ vagyok a többi gyerektől, nekem ha azt mondják, hogy holnap vizsga van, engem az annyira nem érdekel. Nekem az fontosabb, hogy este menjek a jamre, érted, vagy hallgassam a [Szakcsi] Robit vagy bárkit, nekem az a legfontosabb."

A muzsikuslét ethoszának „mi zenészek vagyunk, érted?!” konfliktusa a hivatalos curriculumok elvárásaival hozzájárul a „mi” („cigány zenészek”) és a fenti idézet-

19 A továbbiakban az interjúrészletekből dőlttel emelem ki a hangsúlyos részeket.

20 Pecek Lakatos Krisztián pl. 13 évesen nyerte meg a Magyar Rádió jazzbőgőversenyét, ahol 30 (!) év volt a korhatár, de hasonló sikereket hosszan lehetne sorolni. 
ben szereplő „többi gyerek”, azaz „ők” megkülönböztetéséhez, ami hozzájárul(hat) a többségi társadalomtól való intézményes szankciók révén felerősített társadalmi távolság növeléséhez, miközben a zene szféráján belül az érvényesüléshez szükséges eltérő tőketípusok folytán a presztízs továbbra is biztosított maradhat. Az iskola normatív elvárásaitól és a többi (értsd: nem zenész) gyerektől való felismert távolság a strukturálisan kondicionált zenészhabitus meghatározta érvényesülési stratégiákkal van összefüggésben: már egészen fiatalon az érvényesülés tétje a (jazz) zenei mező dimenziójában konstituálódik. A fő motiváció arra irányul, hogy az általuk elismert nagy presztízsủ (csak romákat említ a fenti interjúalanyom!) zenészek szemében elismertek legyenek.

Míg a nem roma származású zenészektől a „hogyan lettél jazz-zenész?”, „Hol tanultál?" kérdésekre a válaszok általában egy tipizálható narratíva körül csoportosulnak, melyben felsorolják a konzervatóriumot, majd a Jazz Tanszéket és a különböző, eleinte nem jazzhez, hanem populárisabb müfajokhoz köthető zenei referenciákat, addig a roma zenészeknél a zenésznarratíva megkonstruálásának kezdete jóval az adott zenész születése elé, generációkkal korábbra esik. E narratíva társadalmilag, történetileg és kulturálisan kondicionált azonossága a kulcs az esztétikai különbségtételek etnikai dimenziójának megragadásához a magyar jazzben. Ahogy a Buendía családban a vissza-visszatérő nevek folytonossága a „magány” generációs stigmájának nyomatékosítását szolgáló múvészi eszközként funkcionál (Márquez 2017), a cigányzenészek körében a generációkon át hömpölygő visszaköszönő nevek a folytonosság kvázitudatos illusztrációjának felelnek meg. Az apákról, nagyapákról való elnevezés folytonosságot biztosító szimbolikus gesztusa változó körülmények és kontextusok közepette is kapcsolatot teremt a zenész felmenőkkel, mi több, a példaképek közvetítette látens elvárások kvázitudattalan praxisokat generálnak és termelnek újra. $\mathrm{E}$ „cigányzenész” narratíva tipikus elemei a felmenők iránti számcímekben ${ }^{21}$ is megjelenő „nosztalgikus” tisztelet, a VIII. kerület bérházainak kölcsönösségen alapuló szomszédsági viszonyai, a hétköznapokat és családi eseményeket egyaránt átitató zenei környezet magától értetődő, „doxikus” tapasztalata (Bourdieu 2001), az otthon intim szférájában történő rendszeres zenei happeningek, ahol olyan autoritások, mint pl. Pege Aladár, hétköznapi vacsoravendégekként vagy akár mint rokonok bukkantak fel. Továbbá a köreikben kultikus Mátyás tér, „a bizonyos budapesti Harlem” (sic !) (Csepregi 2009), koncentrált, „focistákból és cigányzenészekből” álló miliője, amit egy interjúban Szakcsi Lakatos Béla (2013) egyenesen a „cigányság központjának” titulált, ahol a jazz műfajával és a jazz-zenészekkel való első ismerkedések is történtek a szóban forgó cigányzenész családba születő, de már jazzt játszó középgeneráció körében. ${ }^{22}$ Szakcsi így emlékezik vissza a Mátyás térre egy Hadas Miklós által 1981-ben készített interjúban:

$21 \mathrm{Pl}$. a „My heritage”, „For my people” vagy „8th district” számcímekben.

22 „A jazz meg nyilván a Mátyás téren jött, futballozás közben” - válaszolja Oláh Kálmán egy interjúban (Oláh 2002), de számos zenésztől, pl. Egri Jánostól is találunk szinte szó szerinti beszámolókat. A „budapesti Harlem” szókép is jól láttatja a strukturális homológiát Magyarország „kvázi feketéi” és az 52. utcában jazzt játszó amerikai feketék között. 
„Ez mind a Mátyás tér és a VIII. kerület volt, akkoriban mondták is, hogy cigány jazz-zenészek. Ma már kevesen tudják, hogy a jazz a Mátyás téren alakult ki. Pegéék, Ungár Pista és társaik a Konti utcából valók. (...) Aztán jöttünk mi, a Mátyás tér környékiek, hozzánk tartozott még Balogh Jenö zongorista, és már nött fel az alattunk lévő generáció: az Ablakos testvérek, Jávori Vilmos, Németh János (Szakcsi 1981).”

A Lakatosok, Baloghok, Oláhok, Pecek Lakatosok, Balázsok stb. városi térben jól lehatárolt miliője volt ez a „jazzkeltető” nagyjából a '80-as évek végéig. A téren focizó kezdetben tipikusan szülői befolyásra még a családi tradíciónak megfelelő hangszerrel (pl. hegedúvel) kezdő - akkori fiatalok zenekart alakítottak (pl. Trio Midnight), akiknek a gyerekei, az „ifjabbak”, ${ }^{23}$ együtt nőttek fel, egy generációval később már közös zenekarokban találjuk őket - és már be is léptünk a jelenbe, ahonnan a kutatásomat megkezdtem a 2010-es évek közepén. ${ }^{24}$

Ebben a miliőben a zenei tradíció tudatos átadása természetes, már az előtt elkezdődik, hogy a gyermek n éhány éves korában fizikailag is képes hangszert fogni a kezébe. Ennek kifejező szimbóluma Egri János nagybőgős Moods c. lemezének (1998) belső borítója, ahol az egyéves (mára énekes és jazz-zongorista) kisfia, akit a nővére tart a kezében, nyúl apja basszusgitárjáért. A borítón szereplő kép meggyőzően reprezentálja család és zene összefonódását, egyben a Köztársasági Érdemkereszttel kitüntetett bőgősnek a kávéháztól a „palotáig” vezető rögös útját is. Egri János apja és - Seress Rezsővel is együtt játszó - nagyapja (Egri János) cigányzenész nyomdokain először hegedűt tanuló, végül jazzbőgőre váltó Egri János kisfia (ifj. Egri János) már az elektromos basszusgitárért nyúl, ami a késő modernitásba való belépést, a technológia teremtette esztétikai kifejezőeszközökben beállt változást is szimbolizálja, hiszen a kávéházi cigányzenészek kizárólag akusztikus hangszereken játszottak. ${ }^{25}$

A generációk váltakozása során identitássá vált zenébôl és zenével élés tradíciója a „mi” és „mások” distinkció lényegi aspektusa, ahogy az a most 19 éves zenész, a legfiatalabb generáció tagjának közléséből is egyértelműen látszik: „ha összeáll a család, miröl beszéljenek a zenészek...? Csak a zenéröl, érted?”. Ugyanez a közlő gyermekkori traumaként említi, hogy cigányzenész édesapja - aki szinte mikortól már járni tudott, vitte magával koncertekre - egy alkalommal, mikor a neves Járóka Sándor prímással volt fellépése, nem engedte a színpadon játszani, mire ő sértettségében 6 évesen egy hétig nem szólt az édesapjához, aki ilyen „arcátlanul” megtörte a családi hagyomány szentségét apa és fia közt. A roma zenészcsaládokban a hangszerismeret nem pusztán mint tradicionális megélhetési forma reprezentálódik, de a közösségbe tartozás kulcsmotívumaként van jelen, melynek fontosságát a nyelv analógiája jól szemlélteti.

23 Pl. ifj. Egri János, ifj. Oláh Kálmán, ifj. Balázs Elemér stb.

24 E folytonosságot jól illusztrálja a Fonóban (2017. 12. 10.) megrendezett „Trio Midnight és zenész gyermekeik” címú koncert is.

25 A jazz és a cigányzene/magyarnóta közti egyik legszembetűnőbb különbség az, hogy az ezredfordulóra a hungarikumnak számító tradicionális vendéglátós cigánybandák szinte teljesen megszűntek, a pesti, és más városok éjszakáiban való évszázados tündöklésük e tanulmány írásakor már leáldozott, melynek szomorú mementója a 2017-es újévi Mága-koncert, ahol a Monti Csárdást egyes beszámolók szerint playbackről játszották. A kávéházi cigányzenének „a kegyelemdöfést a mulatós zene adta meg" - nyilatkozik egy zenészcsaládba született roma származású interjúalanyom. 
A „választékos beszéd” polgári ideáljánál fontosabb szereppel bír a zenei diszpozíciók anyanyelvi szinten történő elsajátítása, noha hasonló funkciót tölt be, mint a társadalmi különbségekre visszavezethető korai szocializáció során (tudattalanul) elsajátított „szép beszédben”, „illendőségben” megragadható modorváltozatok (Bourdieu 1978). A cigány származású, de - interjúalanyom kifejezésével élve - „nem cigányos”, vagyis „gádzsós” jazz-zenészt épp a „választékos beszéddel” és a „nem roma baráti körrel” (sic!) azonosították, szemben a roma zenész által romákhoz (hozzájuk) társított, a többségi társadalom pejoratív asszociációit magán viselő „bohém”, „bulizós”, „harsány" kategóriákkal:

„Vannak a cigányoknak olyan dolgai, hogy nagyon szeretnek inni, nagyon szeretik a zenét (...). Van olyan cigány, aki gádzsós, ez a fordítottja, aki nagyon választékosan beszél, mindig, megvan a baráti köre, akik nem cigányok, rá azt mondják kicsit, hogy "gádzsós«."

A zenei szocializációt „törzsi belenevelődésként” interpretáló mechanizmust a zenei diszpozíciók korai elsajátításaként értelmezem. Ahogy egy magas kulturális tőkével rendelkező (szak)értelmiségi családban a magasabb szintű nyelvi kódokat sajátítja el nagyobb valószínúséggel az odaszülető gyermek, úgy nem meglepő, hogy többgenerációs - esetenként évszázadokra visszavezethető - zenei múlttal rendelkező cigányzenészek esetében a zenei szakzsargon, a hangszerekhez, zenéhez kötődő természetes, és nem intézményes ${ }^{26}$ körülmények közt tanult vagy elsajátított viszony „inkorporálódik” már kisgyermekkortól kezdve, és válik habituális elemmé. Inkorporáció alatt Bourdieu alapján a tudat alatti elsajátítási folyamatot értem (Wessely 2005), ami által a jazzben is (de tágabb értelemben a zenében) tőkeként értelmezhető kvalitások („hallás”, hogy jó „füle van-e”, ritmusérzék, „zeneiség”, technikai tudás stb.) úgy épülnek be már a korai szocializáció során, mint másnál az anyanyelv: erôfeszités nélkül, tudat alatt. A zenei szocializáció során elsajátított habitust a roma zenészek leginkább dogmatikus csoportja magától értetődő, doxikus tapasztalatnak éli meg, sőt a fentebb hangsúlyozott folytonosságot a legkevésbé elidegeníthetetlen "genetika” vérségen alapuló, antiintellektuális kategóriájával konstruálják meg, melynek hús-vér valósága nem szorul bizonyításra: „zeneiség” és cigányság ebben az egy és ugyanaz elidegeníthetetlen önazonosságát alkotja. Elsősorban nem olyasmi, amit különböző hatások folytán intézményekben megtanulnak vagy tudós referenciák tanulmányozása során elsajátítanak (pl. a free jazzben), de a dolgok belülről fakadó, anyatejjel magukba szívott, „genetikailag kódolt” természetes rendje. Ebbe az értelmezési rendszerbe illeszkedik, hogy sokan önmagukat a feketékhez hasonlítják, s az elnyomott etnikum ösztön szintjén létrehozott zenei referenciáit tartják legitimnek: „Nekem személy szerint megerösitést jelentett, hogy képes voltam fekete zenészekkel is

26 Ez nem jelenti azt, hogy a képző intézményekben (konzikban) már egészen kisgyerek kortól kezdve ne tanulnának zenélni, és ne lenne komoly tanulás az eredményeik mögött. Mégis, amit e fejezetben hangsúlyozok, azok a családi hagyomány folytán, a szocializáció során kialakuló zenei diszpozíciók, melyeket a zeneiskolába „visznek” magukkal a zenészcsaládba született diákok. 
együtt játszani" (ifj. Szakcsi 2005). A genetikailag konstruált elidegeníthetetlenség jelenik meg (pl. „fekete nyelvezet”) akkor is, amikor rákérdeztem egy roma származású zenésznél, miért fontos fokmérő vagy összehasonlítási alap, hogy feketékkel játszik:

„Mert ez [a jazz] az övék! Akármennyire európai zene is kellett hozzá, hogy fejlödjön, azért mégiscsak afroamerikai, ezt ők tudják legjobban."

A (mainstream) jazz körökben legendás első generációs jazzdobosra, Pecek Lakatos Gézára való visszaemlékezés pedig történeti perspektívából illusztrálja a művészetből, vagyis a jazzből élő elnyomott etnikum és rassz domináns frakciói közti strukturális homológiát és a mainstream esztétika etnikai konstrukcióját is. Ráduly (2015) visszaemlékezésében pl. a mainstream esztétika („,könyörtelen szvingelés”) a „vérség” és a(z) (elnyomott) rassz kontextusában jelenik meg, ráadásul egy közös, doxikus tudásként reprezentálódik, amit nem kell „megmagyarázni”, mert egyértelmű (legalábbis a „bennfentes” zenészek számára):

„A három említett dobos közül [Pecek] Géza volt talán a legvérmesebb, a legzsigeribb, aki könyörtelenül szvingelt (...). Kedvenc szavajárása az volt, hogy ’Black man‘, miközben mélyen a szemedbe nézett és verte a mellét. Csak így: 'Black man', nem 'I'm a black man', hiszen mindenki értette, hogy mit mond - és úgy is dobolt. Hiszen a vér ..., a vér... - és úgy is dobolt (Ráduly 2015)."

A felsőbb osztályok reprodukciójához szükséges, a társadalmi mező domináns hierarchizálódási elvének megfelelő tőkefelhalmozással analóg módon nem pusztán az elsajátított tudás maga, de a tudáshoz való viszony viselkedésmodalitásokban megragadható stiláris elemei válnak a szimbolikus különbségtételek, így a hierarchizálódás alapelveivé. A mainstream jazzt dogmatikusan képviselők, akik - ahogy a következő idézetből is látszik - a zenéhez való összes viszonytípus közül „azt értékelik legtöbbre, amelyen a legkevésbé látszik az elsajátítás fáradsága” (Bourdieu 1978: 45). Ahogy a következő, nagy presztízsű, magát „fanatikus” roma származásúnak valló zenésztől származó idézetből jól látszik a „megtanulható” és „genetikai” adottság oppozíciója, vagyis az, hogy a tanulás révén szerzett képességeiket vérségi alapon legitimálják, és „tőkésítik” a származást:

„A másik, amiért mondják ezt a cigány jazzt, mert ez a fanatizmus...Egész nap muzsikálnak, és ezt nehezen viselik el az emberek, akik kevésbé tehetségesek: megtanulják a véres verejtékkel megtanulhatót, és jön egy tizenéves gyerek, életében nem gitározott vagy zongorázott, odaülteted a hangszerhez, és eljátssza - a cigány jazzbe' semmi más nincs. Genetika, hallod, mért van az, hogy a világ legjobb klasszikus zenészei zsidók? Nagyon egyszerü, van genetikus memória, létezik, nem kérdés, ezt látom a másfél éves fiamon (...). Hogyha egy cigány elkezd zenét csinálni, addig nem nyugszik, amíg hiteles nem lesz." 
Meglátásom szerint ebből a nézőpontból érthető meg leginkább koherensen az etnikai alapú - osztályozó és egyúttal osztályozott csoportként tételezett - „roma jazzistákkal" kapcsolatos különbségtételek logikája a kortárs magyar jazz leképezte kulturális distinkciók kontextusában. A struktúra állandóságára gondolok, nevezetesen arra, hogy a tartós, generációkon keresztül átörökített zenei diszpozíciók múfajtól relatíve független struktúrája alapvetően történeti változások és különböző erőterek (politikai, gazdasági) egymásra hatása nyomán az adott kulturális vagy zenei erőtér kontextusában érvényesül. Így válik a jazz Oláh Kálmán Bartók-interpretációja során a cigányzenével „analóg müfajjá”, ${ }^{27}$ ahol nem a múfaj maga (ami változik), hanem a múfajjal kialakított viszony elsődleges (állandó). A zenei habitus egyben életstílusosztályokat alkotó megkülönböztető struktúra és praxisokat generáló elv, melyet a roma jazz-zenészek a „fanatizmus” jelzővel írnak le, ami már nem zenei kategória, hanem megkülönböztető sajátosságokat magán viselő életforma is egyben:

„Fanatizmus, ezt másképp nem lehet. A zenével nem foglalkozni, gyakorolni kell, hanem élni, ez egy életforma, érted? (...) Minden mást köré kell építeni: család, szex, szerelem, drogok, mindent köré! (...) Csak azért van kör, mert a cigányoknál nem csinálnak mást: csak a zene, és több a fanatikus!"

A terminusokban való tobzódást remélem oldja némileg és egyúttal illusztrálja a mondottakat az a metafora értékű megfigyelésem, mikor egy neves fóvárosi „jazzkávézó” duókoncertjén az első 45 perces szettet a zongorista úgy játszotta le, hogy közben 2 éves (!) kisfia csendben ült a Monk-sztenderdeket éppen játszó édesapja ölében. Ehhez csak hevenyészett adalék, hogy a közönség soraiban ülő (énekesnek készülő) 13 éves kislányának példaképe az egyik neves magyar jazzénekesnő. A fentieket tovább szemléltetendő, álljon egy idézet Pecek Lakatos Krisztián közösségi médiában elérhető életrajzából, mely tűpontos reprezentációját adja a roma muzsikusnarratíva korábban fölvázolt központi elemeinek. ${ }^{28}$

A családjában senkiről nem tud, aki ne zenész lenne. Bőgős apukája (...) édestestvére Pecek Lakatos Géza, így ő a Magyar Köztársaság Érdemrend Lovagkeresztjével kitüntetett, 2005-ben elhunyt jazzlegenda unokaöccse. Három testvére közül a legidősebb Adorján, aki zongorista, a kisebbik bátyja László, aki bőgős és basszusgitáros, Anikó, a nővére zongorista, klasszikus zenész. A lakásban a gyakorló időkön kívül is egész nap ment a jazz, így már 3-4 évesen hallgatta Miles Davis lemezeit. Apukája egy kis csellót vett neki, mert Krisztián állandóan odamászott a lefektetett bőgójéhez, és pengetgette, sőt néha meg tudta fogni a hangokat. A kis csellóval egyre jobban ismerkedett, bőgőként kezelte, de a családi hagyományokat követve, mint mindenki, ő is a zon-

27 „Ők [cigányzenészek] mindent játszanak, csak sajátos stílusban adják elö. Szóval ez majdnem ugyanaz, mint a jazz. Egyébként Bartók is azt mondta, hogy a cigányzene (...) analógiája a jazznek" (Oláh 2002).

28 Elérhető: https://www.facebook.com/krisztianpeceklakatos/posts/803854552958679. 
gorával kezdte zenei tanulmányait. (...) kilenc éves korában kezdett el bőgőzni. Még nem töltötte be a tizedik évét (...), legelső fellépése Szakcsi Lakatos Bélával és Pecek Lakatos Gézával volt.

\section{Az erős kötések ereje: rokonsági viszonyok a zenében}

$\mathrm{Az}$ alfejezetben az etnikum és esztétikum kapcsolatát világítom meg a családi és rokoni kötődésekkel összefüggő tartós beállítódások vagy zenei diszpozíciók szempontjából. A rokonsági kötelékek fontosságát jól láttatja, hogy kutatóként belőlük „készülnöm kellett”, hogy pozíciómat legitimnek, kérdéseimet pedig téttel bírónak tekintsék a válaszadók. A származásra vonatkozó ismereteim a bennfentesség kódjaiként funkcionáltak, kutatóként tőkésített ismereteim pedig belépési adóként értelmezhetők. Egy roma származású kulcsinformátorom pl. a legnagyobb természetességgel beszél a családfakutatók kompetenciájába tartozó rokoni szálak szövevényéről („a Szakcsi Béla bá' felesége a Kálcsi apjának édestestvére" stb.), és addig nem kezelt közel egyenrangú beszélgetőpartnerének, míg kutatóként a legfontosabb rokoni szálakat meg nem tanultam, beleértve a különböző zenészek együtteseit is, akár évtizedekre visszamenőleg.

Mikor a „romajazz-elit” egyik tagjával alkalmam nyílt interjút készíteni, jelen volt szintén két (roma) zenész, akik egy ideig vizsgáztatták az interjút végző kutatót. Megkérdezték például, hogy „Mozart miből jön?”, amire szemérmesen csak annyit tudtam válaszolni: „hát a Bachból”. - „No de melyikből?” - kérdezték kajánul. A kutató múveletlenségének kínos intermezzója után kiderült, hogy a Bach család (!) a fó referencia számukra, és nem Johann Sebastian, akire egyébként naivan gondoltam. A kurzívval szedett 'család' szó nem kizárólag a vérségi kötelékekre utal, noha a vérségi köteléken alapuló, a távoli rokonokra is kiterjedő összetartozás - ahogy az interjúrészletek is megvilágítják - fontos dimenzió. A fentebb már idézett informátortól származik a metaforaértékkel bíró történet két zenész közti konfliktusról, ahol a kötekedő fél „magával baszik ki”, ha inzultálja az illetőt, mert „nem csak vele veszik össze, de öt másik hangszeressel” ${ }^{29} \mathrm{Az}$ adott zenésszel való konfrontálódás tehát érdekellentétes: izolálódással fenyegeti az illetőt, mert az erős kötésekkel bíró közösség összezár és kirekeszt. A határok megvonását verbálisan a „testvér” szóval nyomatékosítják, akkor is, ha konkrét vérségi kapcsok csak távolról vagy egyáltalán nem kötik össze az adott zenészeket.

Nem roma nézőpontból a cigány származású jazz-zenészek egy viszonylag homogén, tradicionalista csoportként jelennek meg (Havas 2017), akiket „mindenki elismer, és akik viszont keveseket ismernek el”. A romák jazzben betöltött elitpozícióját egy alkalommal kontextualizálták az interjúk során szélesebb társadalmi perspektívából. Ahogy a nem roma származású interjúalanyom kifejti, a nem roma származású zené-

29 A hangszert sem közlöm az anonimitás ez esetben is indokolt céljából. 
szek körében „zenei kirekesztésnek” érzékelt szimbolikus erőszak (lásd pl. Bourdieu 2001) a többségi társadalom és a romák közti társadalmi egyenlőtlenségekre vezethető vissza. Ez egybevág azon korábbi feltételezésemmel, mely szerint az esztétikai dogmatizmust (a mainstream jazz esztétikájához való erőteljes ragaszkodást, valamint a jazz definíciójának ez alapján történő megkonstruálását) a társadalmi erőtérben betöltött pozíció kondicionálja. Röviden, a mainstream jazz professzionális elsajátítása a romák körében státuszlegitimáló funkcióval bír:

„Ennek a társadalmi csoportnak folyamatosan védekeznie kell a többségi társadalommal szemben. A romák már azelőtt védekeznek, mielött bárki támadta volna öket - zenészberkekben is. Tehát mindenki, aki mást csinál, azt egyfajta támadásként élik meg zeneileg. Ennek van egy nagyon kemény hozadéka, hogy bár mindenki imádja, ahogy játszik az $X$ vagy az Y, de hogy a közelükbe nem mennének, az biztos. Kevés nem romának van kedve velük játszani, mert azt érzik, hogy csak az elutasítást meg a méregetést fogják tőlük kapni. (...) És elsősorban ez nem zenei konfliktus, ez egy társadalmi konfliktusnak a zenei manifesztálódása. (...) Nekem általában az nem szimpatikus, ha ezt valaki eröszakkal magára veszi valamilyen frusztrációból kifolyólag, és kezd oo is úgy beszélni, mint egy jazz SS-katona, hogy a jazz ilyen, a jazz olyan..."

Az elnyomott etnikum domináns frakciójának zenei kirekesztéssel kapcsolatos megnyilvánulásait a nem roma származású jazz-zenészek egyfajta ellenrasszista diskurzusban interpretálják. A 'jazz SS-katona' vagy 'bebop polizei' (sic!) kifejezések a mainstream jazzt ideologikusan képviselő jazz-zenészek státuszkompenzáló és státuszlegitimáló kizárási aktusainak a verbális minősítései azok részéről, akik e privilegizált körön kívül vannak. Azonban ha közelebbről szemléljük a relációkat a jazzzenészek között, akár megnézzük az egyes együttesek összetételét és azt, hogy kivel játszanak szívesen a zenészek, a cigány-nem cigány dichotómiánál árnyaltabb képet kapunk. Ezért a fejezet során az átjárás és a befogadás kódjaira is figyelmet szentelek, hogy érzékeltessem, milyen árnyalatai, illetve strukturális variánsai léteznek e megkülönböztetésnek.

A durkheimi értelemben „társadalmi tényként”30 funkcionáló megkülönböztetés - a roma származású jazz-zenészekhez romák és nem romák által egyaránt társított (!) homogenizáló sztereotip kategóriák - a gyakorlat során nem merev elzárkózásban nyilvánul meg, ahogy ez tapasztalható a mainstream és free jazz ellentét kapcsán, mely csoportok nem járnak egymás koncertjeire, és ad hoc formációkban is csak nagyon ritkán találkoznak. Inkább az intimitás etnikailag konstruált kódjairól van szó, aminek esztétikai aspektusa a mainstream jazzhez való erős, dogmatikus ragaszkodás közös tapasztalata, gyökere viszont a zenei tradíció generációs tapasztalatában keresendő. A túlnyomóan roma származású zenekarokban is találunk nem romákat, és

30 Az egyes egyénektől független objektív struktúrát (Durkheim 1978: 23-94) értek e kollektív ítéletek alatt, melyek, ha nem is kényszerként hatnak a gyakorlatokra, de kondicionálják azokat és más társadalmi tényekkel magyarázhatók, ami alatt a strukturálisan alárendelt pozícióban lévő városi magyar zenész cigányok történetileg kondicionált habituskonstrukcióinak a (zenei) szocializáció folytán történő, generációkat átívelő újratermelési mintáit értem. 
fordítva. Annak megválasztására, hogy kivel zenélnek együtt, a „kiterjesztett család” analógiája szerint értelmezett „belső kör” felé irányuló elfogultság van hatással, egyfajta pozitív diszkrimináció, aminek lényegét egy nem roma származású jazz-zenész a következőképp foglalja össze: „ők másokkal is szeretnek játszani, csak ha lehet választani, inkább egymást választják”. A pusztán etnikai alapú merev szegmentálódást árnyalja azzal a roma származású zenésszel készült interjú, aki a származással, a mindent a zene köré szervező „fanatikus” életstílussal összefüggő zenei habitus esztétikai és életviteli sajátosságai alapján fogadja el zenekari társának a nem roma zenészt is. Sőt, az interjúban etnikai származástól függetlenül alkalmazza - igaz, ironikus éllel - a "gádzsó” kifejezést:

„[XY jazz-zenészt] azért nem mondom gádzsónak, mert az, aki képes odafigyelni hét emberre, akkor az már nem az, hogy gádzsó... A cigányok közt is nagyon sok gádzsó van, és hiába zenész, nem tud kommunikálni. (...) Ha szólózni kell, leszakítja a csillagos eget, de az első neki mégis az, hogy kommunikál."

A fenti interjúrészlet meglátásom szerint jól reprezentálja azt, hogy a belépési adó lényegi eleme a családi intimitás analógiájaként megjelenő odafigyelés, együttjáték és kommunikáció, valamint a zenészek közti reciprok viszonyokon alapuló szimbolikus egalitarianizmus, ami az interjúban az öncélú, virtuóz szólózással van szembeállítva. Az idézetben nem megnevezett zenész már nem „gádzsó”, aki nem tud együtt játszani, de a történetileg és etnikailag konstruált zenészhabitust elsajátító „kvázicigány” zenész, akit más, nem roma származású mainstream zenészek egyébként nekem személyesen is kritizáltak, korántsem zenei alapon, de az életstílusával, ha tetszik a köznapi értelemben vett habitusával összefüggésben. ${ }^{31} \mathrm{~A}$ cigány/nem cigány megkülönböztetés elsősorban nem a mainstream jazzjáték egyfajta tradicionális cigányzenében gyökerező esztétikai sajátosságaiban (pl. virtuozitás) ragadható meg, hanem a mainstream jazz esztétikájának etnikai alapon történő kisajátításában, melyet a következő szituáció is jól illusztrál. Miután egy jam session alatt egy odatévedt, ismeretlen külföldi zenész beszállt játszani, a vele játszó roma származású zenész a közös improvizáció után azzal dicsérte meg a játékát, hogy „jó cigány vagy!”. A „jó cigány vagy" (sic!) ebben a kontextusban arra utal, hogy a cigányok tudnak igazán mainstream jazzt játszani, akkor is, ha az illető ezt a „bókot” félig ironikus megjegyzésnek szánta. A „jó cigány” (szemben a „gádzsó” jelentéstartalmaival) nem származás alapján, de habituálisan konstruálódik, ami összefügg azzal, hogy a romák és nem romák által mainstream elitnek tekintett közeg (bárkit megkérdezhetünk a szcénában, ugyanazokat a neveket fogja mondani) válik követendő mintának a magyar jazzszcénában. Az ide sorolt zenészek a rangok legitim elosztóiként jelennek meg, akikkel „presztízs együtt játszani”.

A megkülönböztetett különbségtételeket és a zenei habitus aspektusait megfigye-

31 A sztereotip módon roma jazz-zenészekhez sorolt életstílus pejoratív attribútumaival (iszik, drogozik, nagyképú, arisztokratikus, túlkompenzál, „züllött” stb.) címkézik egyesek. 
lések és mélyinterjúk rekonstrukciója alapján bináris oppozíciók szerint modellező kutatásom számára kifejezetten fontos volt olyan helyzetek etnográfiai leírása, melyek árnyalják a fenti képet a „romák összetartásáról”. Egy jam session-ön például teljes összhangban játszott együtt az öttagú zenekar, akik közt „csak” egy neves zenész volt roma származású. Ebben semmi különös nincs - ahogy utaltam rá, a közeget nem etnikailag homogén csoportok alkotják, és a mainstream jazz elsajátítása belépési adó még a legnagyobb presztízzsel bíró történetesen roma származású körökbe is. Azonban - figyelve a koncerten és a koncert után történő interakciókat - a szóban forgó zenész a teltházas előadás közönségéből a koncert szünetében ahhoz ment oda, akiknek az asztalánál a jamre egyébként gyakran járó roma zenészek is ültek. Nem maga a tény ragadta meg a figyelmemet, hanem a bennfentesség és intimitás gesztusai, az öleléssel és „puszival” köszönés, a családias hangulat, ami az akkorra etnikailag homogén asztaltársaságot körbelengte. Ez a szituáció - és száz másik, melyeket leírhattam volna - jól illusztrálja, hogy tipikusan nem a kifelé irányuló kirekesztés manifeszt gesztusairól van szó, hanem a saját körön belül gyakorolt és közösen megélt intimitásról. Ezt a távolságtartást és határmegvonást (sarkítva: ki számít „tesónak” és ki nem) a nem roma származású zenészek egyfajta arisztokratikus távolságtartásnak érzékelik.

Koncertszervezői tapasztalataim is hozzásegítettek a családi alapon konstruált „erős kötések” erejének érzékeléséhez. Az épp aktuális formáció tagjainak összeállítását az esetek többségében az adott zenészre bíztam és bízom, nem szólok bele, kikkel jönnek el játszani. Mikor legutóbb felhívtam az egyik fiatal roma származású zenész ismerősömet, hogy van-e kedve játszani, feltettem neki a kérdést: Eljönnél az XY-nal zenélni? (Olyan nem roma származású zenészt említettem, akivel már játszottak együtt, csak akkor őt kérdeztem meg, hogy kivel játszana, s ő a szóban forgó roma zenészt nevezte meg.) Ez esetben azonban visszakérdezett az illető, hogy nem jöhetne-e inkább két közeli rokonával, feltéve, ha „lehet választani”. Lehetett választani, egyúttal számomra a sokadik ilyen szervezői tapasztalat után vált világossá, hogy a verbálisan eszkalálódó és sztereotípiákra okot adó konfliktusok elfedik a lényeget, vagyis a családi alapon való összetartozás szerepét e fejezet során tárgyalt felismert különbségtételben. Meglátásom szerint a „ha lehet választani” felém intézett megjegyzésben szintetizálódnak az esztétikai preferenciák a családi összetartozással. A roma zenészcsaládba született jazzzenészek, ahogy az előző fejezetben is utaltam rá, a közös történeti tapasztalat mellett, ha nem is mindig vérségi, de rokonsági kapcsolatok hálójába ágyazódnak, ahol még az oly távoli rokon is, mint a „másodunokatestvér”, az összetartozás, a „mi” konstrukciójának bináris kódját jelöli. A szerteágazó családi kapcsolathálók erős kötései nyomán már a kora gyermekkori szocializáció során megismerik egymást a családok különböző ágainak leszármazottai, a felmenők erős kötései reprodukálódnak az újabb generációban, ami hozzájárul egy zártnak érzékelt intim közeg létrejöttéhez, amit a jazzben pl. közös zenekarok alapításában tőkésítenek. Ebben nagy szerepe van annak, hogy a zenész szülők generációja ugyanúgy elviszi koncertjeikre az „ifjabbakat”, mint anno őket vitték zenész szüleik, természetessé válik, hogy együtt kényelmesen tudnak játszani, s ezt a 
meghittséget és évtizedek alatti „összeszokást” tipikusan esztétikai kategóriákkal írják le. A fejezet címére reflektálva a kortárs jazz kontextusában az erős kötések ereje pont a családi, rokonsági, illetve a közös történeti tapasztalatban gyökerező kölcsönös szolidaritásban nyilvánul meg. Ezáltal biztosítanak és szilárdítanak meg monopolpozíciókat és juttatják kölcsönös előnyökhöz e belső kör tagjait, szemben a fragmentált, gyenge kötések fontosságával, ahogy arra Granovetter (1973) alapmúvében a munkapiaci előnyök kapcsán rámutat. ${ }^{32}$

A szocializáció, a család kötelékei nyilvánulnak meg e választásokban, ahol a preferenciapiramis csúcsát mindig a család jelenti. A család elsőbbségét kiválóan szemlélteti az a szituáció is, mikor a kávézóban ülve a jazztanszak egyik tanára a fülembe súgta, hogy „elsô a család”, amikor a kávézóba - rólunk először tudomást sem véve -belépő roma származású neves zenész először az ajtótól jóval távolabb lévő családtagjainak köszönt, és nem minket üdvözölt. Mindkettőnk meglepettségét némileg feloldandó - számára a társaságomban kínosabb volt, hogy neki, mint egyetemi és zenész „kollégának” nem köszöntek - az „első a család” hozzám intézett bizalmas megjegyzése annak a felismerésnek adott hangot, hogy a számunkra akkor evidens térbeli távolsággal egyenesen arányos üdvözlési sorrend az illetőnél a társadalmi távolság logikáját követte, mely kontextusban korántsem sértés volt a felénk irányuló látszólagos ignorancia, hanem konzekvens viselkedési minta.

A következő roma származású interjúalanyom a cigány/nem cigány különbségtétel lényegének a kölcsönösen osztott zenéhez való viszonyt említi, ami meglátásom szerint jól összeegyeztethető a zenei habitus fogalmával.

- H. Á.: Akkor ez egy tévhit, hogy a cigányok szeretnek együtt játszani?

- X. Y.: Nem hülyeség egyáltalán. A romák képviselnek egy stílust Magyarországon, ami nagyon nagy színvonalú stílus: Kálcsi, Robi, Béci, öreg Szakcsi, Tzumo...

- H. Á.: Ez azt jelenti, hogy nagyon magas színvonalon játszanak mainstream jazzt, vagy azt, hogy máshogy játsszák?

- X. Y.: Máshogy. Nagyon magasan játsszák, a legnagyobb zenészek, akiket elmondtam, de az a fontos, hogy más stílus! Általában aki roma, azok megértik egymást, ezért van az, hogy a Szakcsi Robi a Pecek Krisztiánnal, Orbán Gyurival, Balázs Elemérrel és Pecek Andrissal [játszik], és ennyiból ki van lőve, más nem jöhet szóba, mert ök értik meg egymást. (...) A romák egyfajta stíluson belül nagyon megvannak egymással (...), ez az igazi mainstream jazz a bebop, de kicsit hard bob is, érted... (...) Nem cigány valaki odamegy játszani, akkor lehet, hogy nem tudják úgy összehangolni egymást.

- H. Á.: Akkor is, ha az illető tök jó hangszeres?

32 Ugyan terjedelmi okok miatt sem tudom mélyebben elemezni a "gyenge kötésekkel” kapcsolatos kiterjedt diskurzust, Granovetter (1973) cikkékre adott válaszában Gans (1974) azt rója fel a szerzőnek (aki az ő adatainak újraelemzése révén írta meg sokat citált cikkét), hogy túlértékeli a gyenge kötések erejét, és nem vesz figyelembe kulturális, történeti és "kiváltképp" politikai szempontokat, melyek alapvető fontossággal bírtak a bizalom kialakulására és a munkaerőpiaci érvényesülésre a kutatott bostoni West End városrehabilitációs kontextusában. A Harvard és Columbia Egyetemek két prominensének vitáját a kérdésben továbbá lásd az AJS 1974-es második, szeptemberi számában. 
- X. Y.: Nem attól függ, hogy valaki jó hangszeres-e, hanem hogy hogyan viszonyul a játékhoz.

A fenti dialógusból egyértelműen kiderül, hogy egyrészt van alapja a jazzszcénán belüli „mainstream elit” megkülönböztetésnek, másrészt, hogy a zenei preferenciák a családi intimitás analógiája szerint működnek. Arra a kérdésemre, hogy a cigányok mainstream jazzt játszanak-e magas szinten, vagy inkább arról van szó, hogy a mainstream jazzt máshogy játsszák, azt a választ kaptam, hogy (verbálisan számukra is nehezen megragadható) eltérő stílust képviselnek a mainstream jazzen belül. Fontos azonban megjegyezni, hogy ezalatt a zenei habitusnak értelmezett zenéhez való hozzáállás közösségét értik, nem azt, hogy „cigányosan” („nagy amplitúdóval”, „érzelmesen”, „virtuóz módon”) játszanának mainstream jazzt, ahogy a következő roma származású interjúalanyom is nyomatékosítja:

„Én nem fogok cigányosan játszani zenét, mert nem tudok. Jazzt tanultam gyerekkorom óta. Nem tudom azt az ízt játszani, én kettô-négyesen frazírozom, nem tudok csárdást kettônégyes frazír nélkül."

A nagy presztízsű roma származású jazz-zenész interjújából egyértelműen kiderül, hogy a zenei referencia számukra a mainstream jazz, és már nem tudják játszani azt az „ízt”, ami a kávéházi cigányzenét jellemezte. Izgalmas volt megtapasztalni, hogy a romák által is felismert magas presztízsű kör néhány tagja a feléjük irányuló kritikákat (kirekesztés, arisztokratikus attitűd, lenézés, méricskélés, státuszhierarchia játékban és verbálisan történő kifejezése) esetenként egyfajta státuszukat alátámasztó bóknak tekintik, magukat - és zenei referenciáikat - emelve a jazzhierarchia csúcsára:

„Család, ez a jazz, ebből indul ki a jazz, a családból. (...) bárcsak mindenki ebbe a kategóriába akarna felnöni. Ehhez fel kell nöni jazzistáknak.”

Ami megjelenik az interjúban, az az, hogy a „családhoz” fel lehet és - ez egyfajta imperatívuszként fogalmazódik meg - fel is kell nőni. A kortárs jazz „etnikai konstrukciója” arra utal, hogy az afroamerikaikat hivatkozási alapnak tekintő, zenészcsaládba születő jazz-zenészek számára „A” jazz - ami kizárólag a „sztenderd” és a mainstream lehet! - egyfajta közösségi kifejezőeszköz-rendszer esztétikai vonatkozása.

A tanulmány végén kísérletet teszek öt habitustípus megkülönböztetésére az interjú és a megfigyelések alapján, melyek árnyalják a roma/nem roma egyébként szignifikáns különbségtételt a magyar jazzszcénában. E különböző habituskonstrukciók további kutatásokat igényelnének, mindazonáltal felhívják a figyelmet arra, hogyha közelebbről szemlélődünk, a történetileg kondicionált „cigányjazzhabitus” alvariánsait is megkülönböztethetjük, árnyalva egyrészt az egymásról alkotott sokszor leegyszerûsítő képet, másrészt magát a történetileg kondicionált zenei habitust. 
Az első típusba tartozik a magát (1) fanatikus jazz-zenésznek aposztrofáló muzsikus, aki a mainstream jazz (sztenderdek, szving, frazír) esztétikáját teszi meg az egyedüli legitim jazzpraxisnak. Ők, a „bebop polizei”, alkotják azt a tábort, akik tipikusan egy zárt - a fenti interjúban is említett - körrel játszanak együtt, és magukra mint követendő példára tekintenek, akikhez fel kell nőni, amit adott esetben elitistának és arisztokratikusnak érzékelt verbális és viselkedésbeli megnyilvánulásokkal is nyomatékosítanak. Nem ritka, hogy bár felnéznek rájuk, sokan - a romák közül is - „tartanak tőlük”, nem keresik a társaságukat, mert úgy érzik, folyamatosan „vizsgáztatva vannak”. Olyannal is találkoztam, aki (2) hagyományos roma zenészcsaládból származik, azonban roma zenészként maga is részint azonosul a romákat ért kritikákkal, és egyenesen kirekesztésről és rasszizmusról beszél. Az interjúrészletben egyúttal jól reprezentálódik a roma mainstream elitként érzékelt csoport kirekesztő viselkedése, ami azt az észrevételt támasztja alá, hogy korántsem csak free jazz nézőpontból tételezik zárt, elitista csoportnak eme zenészeket.

„Ha nem is mondják ki durván, de éreztetni akarják mindenkivel, hogy eddig és nem tovább, mert mi vagyunk a krém, a legfelsöbb polcon, és mindenki csak alattunk. Ezt tartom megint csak igen szomorúnak, amikor a romák azt mondják, hogy itt Magyarországon az igazán jó jazzt, mi romák tudjuk, mert csak mi tudunk frazírozni, mi ismerjük a szving lüktetését. (...) Én azt mondom, hogy de jól bőgőzik az XY, aki nem roma, „hülye vagy, az a gádzsó csávó vértelen... hogy bőgőzik, az a cigánygyerek tizenhét éves, és kijátssza az agyát" (...) mi túl harsányak tudunk lenni, túlságosan kis sikerek után is (...) beképzeltek tudunk lenni, és rasszisták tudunk lenni, nyugodtan ki lehet mondani, hogy mi romák nagyon rasszisták tudunk lenni, amikor azt mondjuk, hogy gádzsók nem tudnak zenélni, vértelen (...)."

A harmadik típusba például (3) Szakcsi Lakatos Bélát sorolom, aki improvizáló müvészként és (már!) nem jazz-zenészként aposztrofálja magát. Ugyan számára is alapvető, hogy a jazz-zenésznek tudnia kell szvingelni és a mainstream jazzt jól játszani, azonban az improvizáció mint alapvető esztétika paradigma szétfeszíti a mainstream jazz kereteit. Jellemző, hogy klasszikus zenei darabokra játszik improvizált kadenciákat, melynek fontosságát több interjúban hangoztatja, és ő az, akit a nemzetközi kritika a kelet-euróai gypsy jazz megteremtőjeként tart számon, elsősorban a Na Dara (magyarul „Ne félj”) című lemeze miatt. A lemezen a tradicionális (nem kávéházi!) cigányzene, a mainstream jazz és a free jazz elemei keverednek, hangsúlyos a cigányzenére jellemző rubato játékmód, melynek ritmusfelfogása analóg a jazzel, legalábbis tempóérzetben nem áll távol tóle. Az általa adott interjúkban megjelennek kortárs klasszikus zenei referenciák, jellemzően Eötvös Péter, Kurtág György, Ligeti György és Kocsis Zoltán, akikkel személyesen is jó viszonyt ápol. A jazz mellett az operett és a balett müfajában is alkot, valamint jelenleg a Tudás fája címú opera megírásán dolgozik. Interjúk során tipikusan úgy említik, mint a jazz megkérdőjelezhetetlen nagy öregjét, aki viszont már túl van a mainstream jazz honi paradigmáján: számára nem 
a mainstream jazz tökéletes játéka a fő tét, hanem egy különböző zenei tradíciókat szervesen integráló autentikus kelet-európai zene létrehozása, ami különböző legitimitásokkal bíró referenciákból táplálkozik. A másik ilyen zenész, aki „szétfeszíti” a mainstream jazz paradigmáját, noha ő is a jazzből jön, Snétberger Ferenc, akinek játékában szintézisre lépnek latin, jazz-, klasszikus és népzenei elemek. Egyik neves mainstream zenész pályatárs például egy beszélgetés alkalmával feltette nekem a kérdést, hogy vajon „jazz-zenésznek” tekinthető-e.

A negyedik típusba sorolom (4) a roma zenészcsaládba született alapvetően mainstream jazz-zenésznek kategorizált jellemzően fiatalabb generációba (huszonéves) tartozó zenészt, aki bevallása alapján mindkét, a szcénát megosztó esztétikától és körtől egyaránt távolságot és kritikai distinkciót tart. Ugyan a mainstream jazz profi tudása elengedhetetlen eleme identitásának, azonban a kortárs klasszikus és komolyzene, valamint a kortárs modern jazz szintézise is vonzza, és sokkal kritikusabban és kevésbé dogmatikusan alkotja meg a jazz definícióját, mint az első, „fanatikus” csoport tagjai, akikkel azonban szoros, tipikusan családi kapcsolatban is van. Az ötödik csoportba sorolom az egyik interjúban (5) „gádzsós” romának hívott zenészt, akit két dolog különböztet meg az első csoportba sorolt „tiszta” pólustól, akik dogmatikusan képviselik a mainstream jazzt. Egyrészt, a megengedőbb attitűd annak kapcsán, hogy mi tekinthető jazznek. Ugyan magát ebbe a csoportba sorolja, de felismeri, és legitimnek tételez más alternatív jazz-zenei identitásokat és irányzatokat. A másik alapvető dolog az életstílus: a gádzsós jelző nem esztétikai szempontokat takar, de életstílusbeli különbséget, ami megjelenik a „választékos” beszédben és a szélesebb ismeretségi körben, valamint a moderáltabb „fogyasztási” szokásokban is.

\section{Összefoglalás}

Tanulmányomban a roma származású, zenészcsaládba született jazz-zenészek zenéhez való viszonyát és esztétikai gyakorlatait vizsgáltam a zenei habitus Bourdieu nyomán alkotott (Rimmer 2012) koncepciójával. A mélyinterjús és etnográfiai elemzésben egyúttal két felvetést vagy hipotézist is próbáltam árnyalni, ami szorosan öszszefügg azzal a jelenséggel, hogy a városi zenei szórakoztatást kvázi monopolizáló kávéházi zenét, ill. magyar nótát játszó muzsikus cigányság a második világháborút követően már jazzt kezdett el játszani.

Az első felvetésem szerint a romák számára a mainstream jazzhez való erős ragaszkodásban megjelenő esztétikai dogmatizmus a társadalmi mezőben betöltött strukturális pozíciójukkal van összefüggésben. Számukra a mainstream jazz profeszszionális szinten játszása státuszlegitimáló elem, ami az esztétikai szempontokon túl a fejezetekben részletezett életstílussal is összefügg. Másik felvetésem alapján - némileg árnyalva a kiszolgáltatottságot és a kirekesztés különböző formáit hangsúlyozó mainstream, szociológiai és antropológiai cigánykutatásokkal kapcsolatos diskurzusokat (lásd Kovai 2017) - a társadalmilag alárendelt etnikum domináns frakciója, 
a jellemzően városi zenész cigány (romungró) csoport a jazz révén nem csak kompetitív viszonyba kerül a többségi társadalommal, de követendő legitim mintául is szolgál. A fejezet empirikus részeiben a történetileg kondicionált zenei diszpozíciók különböző dimenzióit világítottam meg, elsősorban a zenei szocializáció és a család fontosságát, valamint az életstílus és esztétikai preferenciák szempontjából. Fő következtetésem szerint a mainstream jazzelitnek tételezett csoport esztétikai gyakorlatai, kifejezőeszközei a szocializáció során újratermelt tartós diszpozíciókkal vannak összefüggésben, ami szélsőséges esetben a zenei antiintellektualizmusban ragadható meg, melynek legitimációja vérségi és genetikai alapon konstruálódik, szemben pl. a free jazz-zenészek tudós referenciák kölcsönözte legitimitásával, mely az „autonóm mưvész zenén túlmutató ethoszát” hangsúlyozza. A fejezet során annak is próbáltam nyomatékot adni, hogy noha a belépés nem kizárólagosan „beleszületéshez” kötött, a „roma mainstream” olyan felismert körként reprezentálódik a kortárs jazzen belül, melynek tagjai jellemzően együtt játszanak, és akik szélsőséges esetekben etnikai kategóriává formálják a mainstream jazz esztétikáját. A fejezet végén kísérletet tettem a zenei habitus különböző típusainak bemutatására, melyek további kutatást igényelnek, egyúttal árnyalják a fejezetben leírt zenei habitus esztétikai gyakorlatokban és életstílusban megragadható dimenzióit.

\begin{abstract}
Based on interview analysis and participant observation my research investigates the role of musical dispositions (i.e. habitus) of Hungarian jazz musicians with gypsy background in the acquisition of prestige within the contemporary jazz field. The dispositional elements attached to roma ethnicity are analysed by Rimmer's concept of musical habitus, an analytical tool that draws on Bourdieu's original formulation of the concept. The empirical chapters focus on the musical socialization, group dynamics, lifestyle and aesthetic distinctions. By taking the above factors in the forefront of the analysis, this study aims to establish links between the structural position of the dominant fraction (Hungarian gypsy jazz musicians) of the dominated ethnic group (gypsies) and their aesthetic practices.
\end{abstract}

Keywords: musical habitus, cultural field, jazz, roma ethnicity

\title{
Irodalom
}

Atkinson, W (2011): The context and genesis of musical tastes: Omnivorousness debunked, Bourdieu buttressed. Poetics, 39(3): 169-186.

Bennett, A. (2004): Consolidating the music scenes perspective. Poetics, 32(3-4): 223-234.

Bourdieu, P. (1978): Az iskolai kiválóság és a francia oktatási rendszer értékei. In uő: A társadalmi egyenlőtlenségek újratermelödése. Budapest: Gondolat.

Bourdieu, P. (1984): Distinction. A Social Critique of the Judgement of Taste. London: Routledge.

Bourdieu, P. (1988): Homo Academicus. Stanford: Stanford University Press. 
Bourdieu, P. (1991): Langauge and Symbolic Power. Cambridge: Polity Press

Bourdieu, P. and Wacquant, L. (1992): An Invitation to Reflexive Sociology. Chicago: University of Chicago Press

Bourdieu, P. (1993): The Field of Cultural Production. Columbia University Press.

Bourdieu, P. (1996): The Rules of Art. Cambridge: Polity.

Bourdieu, P. (2001): Masculine Domination. Stanford University Press.

Bukodi, E. (2007). Social stratification and cultural consumption in Hungary: Book readership. Poetics, 35(2-3): 112-131.

Brown, J. (2000): Bartók, the Gypsies, and hybridity in music. In Hesmondhalgh, D. - Born, G. (eds.): Western Music and Its Others: Difference, Representation and Appropriation in Music. Berkeley: University of California Press, 119-143.

Chan, T. W. - Goldthorpe, J. H. (2007): Social stratification and cultural consumption: Music in England. European Sociological Review, 23: 1-29.

DeNora, T. (2000): Music in Everyday Life. Cambridge: Cambridge University Press.

Dregni, Michael (2004): Django: The Life and Music of a Gypsy Legend. New York: Oxford University Press.

Durkheim, É. (1978): A társadalmi tények magyarázatához. Budapest: Közgazdasági és Jogi Könyvkiadó.

Federmayer É. (2017): Millenniumi Budapest és ragtime: A faj, a nem és az osztály (rendiség) mintázatai a korai magyar jazzkorszakban. Replika, (101-102): 41-65.

Gans, H. J. (1974): Gans of Granovetter's strenght of week ties. American Journal of Sociology, 80(2): 524-527.

Gáti A. (2010): Társadalmi háttér és mobilitás. In Garai et al. (szerk.): Diplomás pályakövetés IV. - Frissdiplomások. Bp.: Educatio, 177-192.

Granovetter, M. S. (1973): The strength of weak ties. American Journal of Sociology, 78(6): 1360-1380.

Hadas M. (2001): Pierre Bourdieu-ről. Magyar Lettre Internationale, 40: 13-17.

Hadas M. (2011): Férfikutatások. TÁMOP online-szöveggyújtemény.

Hadas M. (2015): Bourdieu esete az áramló folyóval és a parti sziklákkal Kritikai adalékok a Férfiuralomhoz 17 év után. Buksz, 27(1-2): 55-62.

Havadi G. (2011): Doktrinerizmus, privilégiumok és szankciók a zenei életben. In Kacsuk Z. -Tófalvy T. - Vályi G . (szerk.): Zenei hálózatok. Budapest: L’Harmattan, 129-158.

Havas Á. (2017): A szabadság dogmatizmusa és a dogmatizmus szabadsága. Különbségtételek rendszere a mainstream-free jazz dichotómiában. Replika, 101-102: 169-196.

Havas Á. (2018a): Szegény rokonok: a magyar jazzszcéna szerkezete és rétegződése. PhD-értekezés. Budapesti Corvinus Egyetem Szociológiai Doktori Iskola (kézirat).

Havas, Á. (2018b): The logic of distinctions in the Hungarian jazz field: A case study of Hungarian jazz. Cultural Sociology, (megjelenés alatt). 
Havas Á. - Ser Á. (2017): „Szegény rokonok” - A budapesti jazzszíntér konstrukciója. Replika, 101-102: 147-168.

Hennion, A. (2007): Those things that hold us together: Taste and sociology. Cultural Sociology, 1(1): 97-114.

Hesmondhalgh, D. (2006): Bourdieu, the media, and cultural production. Media, Culture \& Society, 28(2): 211-231.

Jávorszky B. Sz. (2014): A magyar jazz története. Budapest: Kossuth.

Jonhson, B. (2002): Jazz as cultural practice. In Cooke M. (ed.): The Cambridge Companion to Jazz. NY: Cambridge University Press.

Kacsuk Z. (2005): Szubkultúrák, poszt-szubkultúrák és neo-törzsek. Replika, 53: 91110.

Kovai C. (2015): A cigány-magyar különbségtétel és a rokonság. PhD-értekezés. Pécsi Tudományegyetem Kultúratudományi Doktori Program.

Kovai C. (2017): Kemény István munkáinak hatása a magyarországi szociológiai cigánykutatásokra egy antropológus nézőpontjából. Replika, 104: 23-30.

Kovalcsik K. (2006): A „cigány nótától” az „autentikus cigányzenéig”. PhD-értekezés. Liszt Ferenc Zenemúvészeti Egyetem.

Könczei Cs. (2011): A kalotaszegi cigányzenészek társadalmi és kulturális hálózatáról. Kriza János Néprajzi Társaság, 36.

Ladányi J. - Szelényi I. (2005): Van-e értelme az underclass kategória használatának? In Ladányi J. (szerk.): Szociális és etnikai konfliktusok. Tanulmányok a piacgazdasági átmenet időszakából (1987-2005). Budapest: Új Mandátum Könyvkiadó, 470-476.

Ladányi J. (2004): A kirekesztettség változó formái. Budapest: Napvilág.

Lamont, M. - Molnár, V. (2002): The study of boundaries in the social sciences. Annual Review of Sociology, 28: 167-195.

Lopes, P. (2000): Pierre Bourdieu's fields of cultural production: A case study of modern jazz. In Brown, N. - Szeman, I. (eds.): Pierre Bourdieu: Fieldwork in Culture. Oxford: Roman and Littlefield, 165-186.

Lopes, P. (2002) The Rise of a Jazz Art World. Cambridge: Cambridge University Press. Maanen, H. (2009): How to Study Art Worlds: On the Societal Functioning of Aesthetic Values. Amsterdam: Amsterdam University Press.

Márquez, G. G. (2017): Száz év magány. Budapest: Magvető.

Peterson, R. A. (1967): Market and moralist censors of a rising art form: Jazz. Arts in Society, 4: 253-64.

Peterson, R. A. (1992): Understanding audience segmentation: From Elite and mass to omnivore and univore. Poetics, 21: 243-58.

Prior, N. (2008): Putting a glitch in the field: Bourdieu, actor network theory and contemporary music. Cultural Sociology, 2(3): 301-319.

Prior, N. (2013): Bourdieu and the sociology of music consumption: A critical assessment of recent developments. Sociology Compass, 7(3): 181-193.

Retkes A. (2014): Különös metamorfózis. A könnyűzene - könnyű zene? A magyar 
populáris zene a 20-21. században címú konferencián 2014. január 31-én elhangzott előadás szerkesztett változata.

Rimmer, M. (2012): Beyond omnivores and univores: The promise of a concept of musical habitus. Cultural Sociology, 6(3): 299-318.

Savage, M. - Silva, E. B. (2013): Field analysis in cultural sociology. Cultural Sociology, 7(2): 111-126.

Sági M. (2010). Kulturális szegmentáció: „mindenevők”, „válogatósak”, „egysíkúak” és „nélkülözők”? Az „omnivore-univore” modell alkalmazhatósága Magyarországon. In Kolosi T. - Tóth I. Gy. (szerk.): Társadalmi riport 2010. Budapest, 288-311.

Schneider, D. E. (2006): Bartók, Hungary, and the Renewal of Tradition: Case Studies in the Intersection of Modernity and Nationality. Berkeley: University of California Press.

Stewart, M. (1994): Daltestvérek. Budapest: T-twins Kiadó-MTA Szociológiai Intézet Max Weber Alapítvány.

Stewart, M. (2005): Depriváció, romák, underclass. In Ladányi J. (szerk.): Szociális és etnikai konfliktusok. Budapest: Új Mandátum, 453-470.

Umney Ch. - Kretsos, L. (2015): That's the Experience. Passion, Work Precarity, and Life Transitions Among London Jazz Musicians. Work Employment \& Society, 42(3): 313-334.

Varriale, S. (2015): Cultural production and the morality of markets: Popular music critics and the conversion of economic power into symbolic capital. Poetics, 51: $1-16$.

Wessely A. (2005): Szocioanalízisben. Budapest: Buksz (ősz).

Zipernovszky K. (2017): „Ki fog győzni - a jazz vagy a cigány - nehéz megjósolni.” A cigány zenészek megvédik a magyar nemzeti kultúrát. Replika, 101-102: 67-87.

\section{Újságcikkek}

Ráduly Mihály (2015): Hogyan látták Lakatos Pecek Gézát a régi játszótársak. Jazzma. hu.

2015. március 11. Interneten: https://www.jazzma.hu/hirek/2015/03/11/hogyanlattak-lakatos-pecek-gezat-a-regi-jatszotarsak (letöltve: 2018. január 24.)

Szakcsi L. B. (1981): Hadas Miklós interjúja SZLB-val. Vigilia, (október), 703-710.

Szakcsi L. B. (2013): „Isten az én menedzserem”. Gramofon, (ősz), 55-58.

Szakcsi L. B. (2016a): Beszélgetés Szakcsi Lakatos Bélával zenéről, hitről, halhatatlanságról. Hetek, (XX/04).

Szakcsi L. B. (2016b): „Az előadó-művészetben energia és szellem van” - Interjú Szakcsi Lakatos Bélával. Nullahategy (december 8.).

\section{Zenei hivatkozások}


Egri J. (1998): Moods. Infoimpress.

\section{Videók}

Csepregi Gy. (2009): JazzBeszéd Egri Jánossal. Miskolc, 2009. 10. 14. Interneten: https://www.youtube.com/watch?v=d1ex_BILUwQ.

Ferenczi G. (1994): Mi hárman, a család és a jazz. Dokumentumfilm a Trio Midnight zenekarról. Interneten: https://www.youtube.com/watch?v=IOuynSPE1Yg (letöltve: 2017. február 6.). 